\title{
The Issue of Civic Education of a Person in the Pedagogical Heritage of Olexander Stronin
}

\author{
Vadim Pilipenko \\ postgraduate student of the Poltava National University \\ Pedagogical University named after V.G. Korolenko, Ukraine
}

\begin{abstract}
Summary
The article highlights the views of O. Stronin on the problem of civic education of the individual. The key elements of the formation of personal virtues are revealed. It was shown that the teacher saw the key source of civic education of the individual as decent examples of the actions of people of the past and present.
\end{abstract}

Keywords: O. Stronin, civic education, personal example.

The development of civil society is inextricably linked with the upbringing of the individual. Therefore, in addition to important changes in the political and economic spheres, in the forefront of reform in public life based on the principle and humanism, democracy and human rights. The leading role in inculcating the values of the people in modern society belongs to the education sector. The Preamble of the Universal Declaration of Human Rights states that by implementing basic document is education and education that should promote the protection of human rights and freedoms through national and international progressive measures [1].Despite some progress, the system of civic education needs to be improved.

The need for realization of this task pays attention to historical and pedagogical experience. In view of this, I would like to pay special attention to the extraordinary figure in the development of the nineteenth century education, the teacher, scientist, activist of the communist movement in Ukraine Oleksandr Ivanovich Stronin. After all, it was he who was one of the first in the Russian Empire to draw attention to the need to return the educational process to the cutting edge of the civic values of the individual.

The purpose of this article is to thoroughly analyze the place of civic education in the educational activities and pedagogical views of Olexander Ivanovich Stronin. 
Olexander Ivanovich Stronin (1826-1889) lived and worked in very turbulent times. As a result of the Industrial Revolution, the Russian Empire completely plunged into the progressive development of capitalism. The society was on the verge before deep changes. Olexander Ivanovich, being a remarkable intellectual of his time, could not stay away from these processes. Therefore, he became an active champion of new ideals from an early age.

Childhood O. Stronin was in frequent transitions from place to place. The reason for the latter was the service of his father, who, although he was a serf and due to his literacy, was able to become the ruler of the princely estates of the genus Yusupov. I. Stronin had a positive influence on his three sons. From the very beginning, teaching them to reading, he laid the foundation for the future formation of sons as intelligent personalities. The father was able to achieve his free sons and sent them to study. Indicative is the fact that all three sons of I. Stronin subsequently became teachers [4, p.25].

O. Stronin first studied at Priluky District School. After getting free, he continued his studies at the Second Kyiv Gymnasium. In the pursuit of the study of the foundations of building a civil society, In 1845 O. Stronin became a law student at Kiev University St. Volodymyr. Being a well-educated man, Olexander Ivanovich received an extraordinary disappointment from the then lawyers and on the second course of study he transferred to the Faculty of History and Philology [2, p.144]. It has played a key role in choosing a teacher's profession in the future.

O. Stronin's professional formation took place under difficult circumstances - a young, creative teacher could not find himself in the system of conservative education of the middle of the XIX century in the Russian Empire. Therefore, it does not seem surprising that in the first six years of work the teacher changed four educational institutions.

In search of a comfortable environment for self-realization O. Stronin got to the First Poltava Gymnasium. We would like to emphasize that at that time Poltava became the focus of the progressive Ukrainian intelligentsia, which directed its efforts to overcome the total illiteracy that prevailed among the general population. O. Stronin, interacting with the educational and cultural figures of Poltava, as well as attracting patrons from the local gentry, joined the creation of free Sunday schools for the poor, public lectures, public theater, etc. It is important that the teacher himself developed teaching programs, educational literature 
and methodological recommendations for teachers involved in such forms of educational volunteering.

As you can see, O. Stronin 's educational activity was full of desire to be useful for raising the general educational level of society, serving as proof of a clear teacher's civic position. Along with this, the teacher, on the basis of his practical experience, developed a significant theoretical basis, which resulted in the scientific and pedagogical heritage of O. Stronin. Among the issues studied by the teacher, the problems of becoming an educated citizen as an important element of society's development are important. Proceeding from the above, it is important to study the views of O. Stronin on the problem of civic education.

O. Stronin was convinced that the full formation of an enlightened citizen gives him the opportunity to constantly develop. For society, the benefit was that a fully developed person with implanted civil values should become the basis for a stable economic and political development of the state [5, p. 44].

With great expectations for young people in building a new society, O. Stronin emphasized the priority of civic education. After all, it was the citizen who was supposed to take responsibility for creating a new socio-political system. He should have a decent education, be a native of the intelligentsia, and must have a high level of self-awareness, that is, embody the ideal of an enlightened person from the educational concept of a teacher.

The leading source of civic upbringing of personality for O. Stronin were examples of deeds of decent people. He believed that the very personal example most influences the pet, stimulates it to self-development. But, looking for such biographies, the teacher faced unexpected difficulties. In particular, for most European countries, the belonging of the people's heroes to the noble dynasties is characteristic. Thus, educator cited examples of European aristocratic families Warwick, Northumberland, Norfolk, Monforte, Pembroke who became the embodiment of the national spirit for in middle class [6, s.399]. After all, these families, embodying a struggle with kings, an aristocratic pride, carry the revolutionary spirit [6, p.399]. By analogy with Russian aristocrats, the teacher drew attention to the fact that among them a truly educational influence on the awakening of the civil spirit can only have the biographies of A. Kurbsky and Metropolitan Philip [6, p.399]. In the prince A. Kurbsky O. Stronin personified the first Russian dissident, a fighter for freedom, a person with high 
moral qualities, able to provide a good example for pupils as a fighter with royal tyranny. He loved his homeland and brought her military power, but was forced to leave her through a tyrannical king. His work could serve as an example for civic values, but here the teacher emphasized that active polemics were initiated by the prince already when he was in the Commonwealth [6, p. 399]. The use of educational effects of biographies in this case became problematic.

Causes of a limited number of heroic examples among Russian aristocrats O. Stronin was associated with the communal consciousness of the population. Personal heroism, according to the teacher, was always in the shadow of the mass [6, p. 399]. Thus, the educator emphasized the lack of an individualistic civil feeling through the influence on him of a public reflex, which undermined not only general principles in social education, but also negatively influenced the civic- patriotic attitude in society.

A special place in the system of views of O. Stronin's civic education of personality took manifestations of social solidarity and patriotism. In particular, in the "Anecdotal History of the Current War", the teacher noted with enthusiasm that there was a large number of volunteers among medical students who, with the onset of the Russo-Turkish War, entered the Red Cross "[3, p. 2]. The teacher described the true impulse of youth to help their homeland, who was in a state of war with a strategic enemy.

With particular respect the teacher spoke about the well-known philosopher-positivist G. Virubov, who, although he had French citizenship, but decided to volunteer to protect his "natural homeland", arrived in the Caucasus, began active activities aimed at the plunder of male hospitals [3, p.3]. So, in the pedagogical views of O. Stronin, one of the leading sources of influence on the personality in order to spread civil ideals, was an example of human actions as a direct manifestation of the value beliefs of the individual.

Thus, having analyzed the problem of civic education in the pedagogical heritage of O. Stronin, we have a solid foundation to state that it was based not on the theoretical principles of civicism or humanism, but a very real example of the life of well-known personalities. The teacher emphasized the importance of reporting to the younger generation the importance of seeking examples of social ideals among existing people, which certainly exist for every nation, but they may simply be little known. Such "worthy citizens" at the same time were an 
inexhaustible source of civil virtues and direct " methods of their implementation" through a personal example.

\section{References}

1. Zagal'na deklaracija prav ljudini [Universal Declaration of Human Rights] / http://zakon.rada.gov.ua/cgi-bin/laws/main.cgi?nreg=995_015

2. Svetlenko S. Narodolyubets [Patriot] O. Stronin / S. Svetlenko // Kyi'vs'ka starovyna [Kiev an antique] - 2002 . - No. 6 . - P. 143-155.

3. Stronin A. Anekdotycheskaja ystoryja tekushhej vojny [Anecdotal History of the Current War] / A. Stronyn. - With Pb : type. F. Sushchinsky, 1877 . - 48 s.

4. A. Stronyn. Dnevnyk s 1848 po 1888 gody. [Diary from 1848 to 1888 years.] - V. 1 (18631864): [1 st variant, where a lot corrections ] // Russian National Security Council St. Petersburg - f. 752. - d. 3. - 47 s.

5. Stronin A. Rasskazy o carstve Bovy Korolevycha. [Stories about the kingdom of Bovy Korolevich] / A. Stronin : [Soch.] Alexander Ivanova [ pseud .] With Pb : type. F. Sushchinsky, 1873 . - $48 \mathrm{~s}$.

6. Stronin A. Posleslovye: polytycheskaja dyagnostyka y prognostyka $v$ Rossyy [Postwords : political diagnostics and prognosis in Russia] / A. Stronin // Polytyka kak nauka [Politics as science] / St. Petersburg: St. Petersburg: type. F. Sushchinsky , 1872. - P. 329-530. 